\title{
| Can immune therapy cure acute myeloid leukemia?
}

\author{
Robert P. Gale \\ Imperial College London, London, UK \\ Robert Peter Gale MD, PhD, DSc(hc), FACP, FRCP, Visiting \\ Professor Haematology, Centre for Haematology Research, \\ Department of Immunology and Inflammation \\ Imperial College London, London, UK
}

E-mail: robertpetergale@gmail.com

Citation: Gale RP. Can immune therapy cure acute myeloid leukemia? Cell Ther Transplant 2020; 9(2): 8-12.

\section{Summary}

There is considerable progress in immune therapy of diverse cancers. In haematology these advances are mostly limited to lymphoid cancers. Effective therapies include monoclonal antibodies and chimeric antigen receptor (CAR)-T-cells to lymphoid lineage-antigens such as CD19, CD20 and B-cell maturation antigen (BCMA). Gemtuzumab ozogamicin (Myelotarg ${ }^{\circledR}$ ) is the only FDA-approved immune-based therapy for acute myeloid leukemia (AML). Several clinical trials of antibodies to CD38 and CD123 are reported with unimpressive efficacy and safety concerns. Reasons are higher daily production rates of myeloid cells and unacceptable collateral damage to normal haematopoietic cells because of imperfect specificity for AML cells. Potential targets of anti-AML immune therapy are (1) HLA antigens; (2) minor histocompatibility antigens; (3) leukemia-associated antigens; and (4) leukemia-specific antigens.
Data supporting an effective allogeneic anti-AML effect come from studies in recipients of haematopoietic cell transplants with graft-versus-host disease (GvHD) and recipients of donor lymphocyte infusions (DLI). A special problem is a relative paucity of neo-antigens in AML compared with solid cancers because of a low cumulative mutation frequency. Cell immune therapy trials are in progress including CAR-T-cells, CAR-NK-cells and allogeneic NK-cells. Approaches using synthetic biology are being developed. Presently, except for gemtuzumab ozogamicin there are no convincing data of efficacy of immune therapy in AML.

\section{Keywords}

Acute myeloid leukemia, mutations, neoantigens, immune therapy.
Prediction is very difficult, especially if it's about the future. Niels Bohr

\section{Introduction}

Immune therapy is a safe and effective therapy of diverse cancers. In haematology this efficacy is limited predominately to B-cell lymphoid cancers including acute lymphoblastic leukemia (ALL), lymphomas and plasma cell myeloma. Effective therapies include monoclonal antibodies such as rituximab, antibody-drug conjugates such as brentuximab vedotin, antibody-radionuclide conjugates such as 131-iodine tositumomab, bi-specific monoclonal antibodies (BiTE $^{\circledR}$ antibodies) such as blinatumomab (CD20/CD3) and chimeric antigen receptor T-cells (CAR-T-cells) to CD19, CD20 and to B-cell maturation antigen (BCMA). The target of these immune therapies are B-cell lineage antigens rather than cancer-specific antigens. These interventions are more effective than checkpoint-inhibition directed antibodies such as those to PD-1, or PD-1L or antibodies to CTLA-4 active in solid cancers.

One might expect equal success using immune therapy to treat myeloid cancers such as acute myeloid leukemia (AML) and chronic myeloid leukemia (CML). However, this is not so. Early attempts to use immunotherapy for AML treatment (with BCG, C.parvum, or leukemia blast antigens) were not successful [1]. At the present time, there is only one FDA-approved therapy of myeloid cancers, gemtuzumab ozogamicin $\left(\right.$ Myelotarg $^{\circledR}$ ) for AML which was first approved $>10$ years ago, withdrawn and re-approved. Why this discordance? 


\section{What are the reasons for success- ful immune therapy of different blood cancers?}

There are two important differences between myeloid and lymphoid cancers. First is the different structures and kinetics of myelopoiesis and lymphopoiesis. Lymphoid and myeloid lineages are divided (dichotomized) at the level of early progenitors. About at 600 billion cells myeloid cells are produced per day in contrast to only about 10 million lymphoid cells per day, a 60-fold difference. Also, granulocytes and platelets survive only a few hours or days in contrast to lymphoid cells which live years. The implication of these differences is a disruption of myelopoiesis is much more serious than a disruption of lymphopoiesis. One be reasonably well without B-cells, somewhat well without T- and NK-cells but you will die immediately without granulocytes and platelets.

Second this the different targetability of myeloid versus lymphoid antigens. As indicated, the target of immune therapy of lymphoid cancers is B-lineage antigens. These antigens are not cancer-specific such that normal B-cells are targeted along with the cancer cells. Fortunately killing all normal B-cells is compatible with life (normal B-cell function can be reversed by giving intravenous immune globulin [IVIG]). In contrast, it is impossible to replace normal granulocyte production, a situation is incompatible with life.

\section{Is there immune surveillance against AML?}

Considerable data indicate the immune system is effective in controlling lymphomas. For example, lymphoma-risk is markedly increased in persons with immune deficiency or suppression such as those with severe combined immune deficiency (SCID), acquired immune deficiency syndrome (AIDS) and solid organ and hematopoietic transplant recipients. Most of these lymphomas are Epstein-Barr virus (EBV)-related. However, there is a only a small if any increased risk of AML, CML or myelodysplastic syndrome

First Kidney Transplants 2000-2014

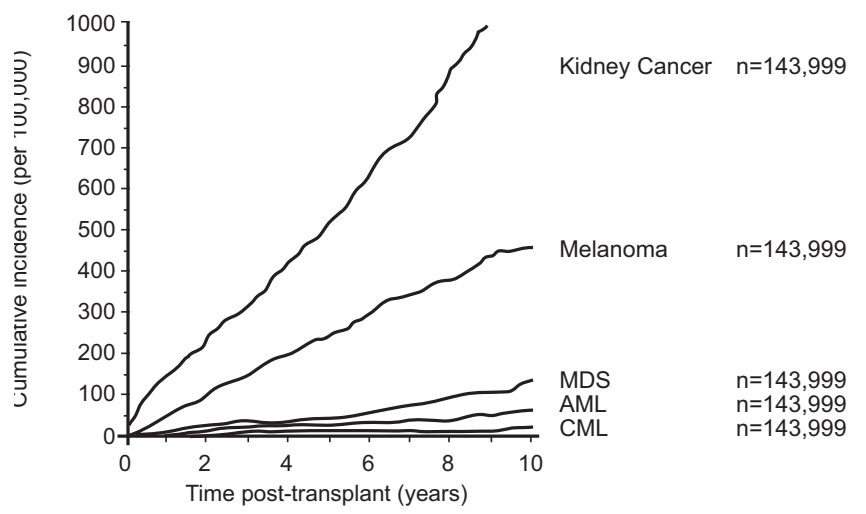

Figure 1. Low levels of myeloid leukemia evolving after kidney transplants $[2,3]$
(MDS) in similar populations and amongst solid organ transplant recipients receiving life-long immune suppression (Fig. 1) [2,3]. These data imply immune surveillance does not operate effectively against myeloid cancers.

\section{Are there convincing data of an immune response to AML?}

Considerable data indicate a strong immune response to myeloid cancers in the setting of a hematopoietic cell transplant. For example, among persons with AML receiving an HLA-identical sibling transplant, cumulative incidence of relapse (CIR) is highest among recipients of a transplant from a genetically-identical twins and lowest among recipients of allotransplants with acute and chronic graft-versus-host disease (GvHD) [4]. This difference correlates with histo-incompatibility between donor and recipient. Graft-versushost disease (GvHD) and graft-versus-leukemia effect $(\mathrm{GvL})$ may be identical or overlap to different degree in individuals.

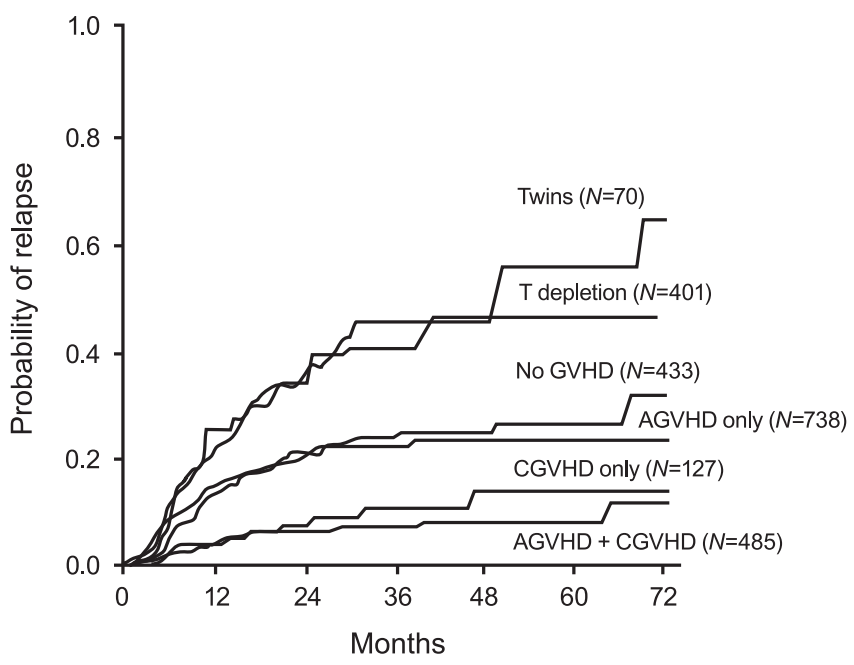

Figure 2. Cumulative incidence of relapse after allotransplants for leukaemia [3]

Therefore, the answer on targetability of AML immune therapy lies in two considerations: (1) lack of a convincing AML-specific target antigen(s); and (2) unacceptable adverse effects from non-specificity of target antigens used in AML immune therapy such as CD33 and CD124. Therapy against these target antigens can potentially kill AML cells but will unavoidably destroy normal bone marrow cells resulting in death absent a transplant or using synthetic biology techniques.

\section{What is the role of AML-specific antigens in graft-versus-leukaemia (GvL)?}

There are several potential targets of anti-AML activity in the context of an allotransplant including: (1) HLA antigens; (2) minor histocompatibility antigens; (3) leukemia-associated antigens; and (4) leukemia-specific antigens (if they exist). All of these are potential targets of the so-called 
GvL-effect seen after allotransplants and after donor lymphocyte infusions (DLI). Elsewhere my colleague and I discuss whether this effect is leukemia-specific or against HLA and/or non-HLA antigens and not leukemia-specific [5].

Several variables correlate with success of immune therapy: (1) antigenicity; (2) immunogenicity; (3) accessibility; (4) sensitivity to killing; and (5) collateral damage to normal cells. The major current limitation of these approaches is lack of an AML-specific target antigen. In many models, probability of response to immune therapy correlates with mutation frequency and with estimated numbers of potential cancer-specific neo-antigens [6]. AML cells have an average of 0.28 mutation per megabase of DNA compared with 8.15 mutations for lung cancer, 40 -fold less. For this reason checkpoint-inhibitor antibodies and antibodies to CTLA-4 are unlikely to be effective when used alone in persons with AML.

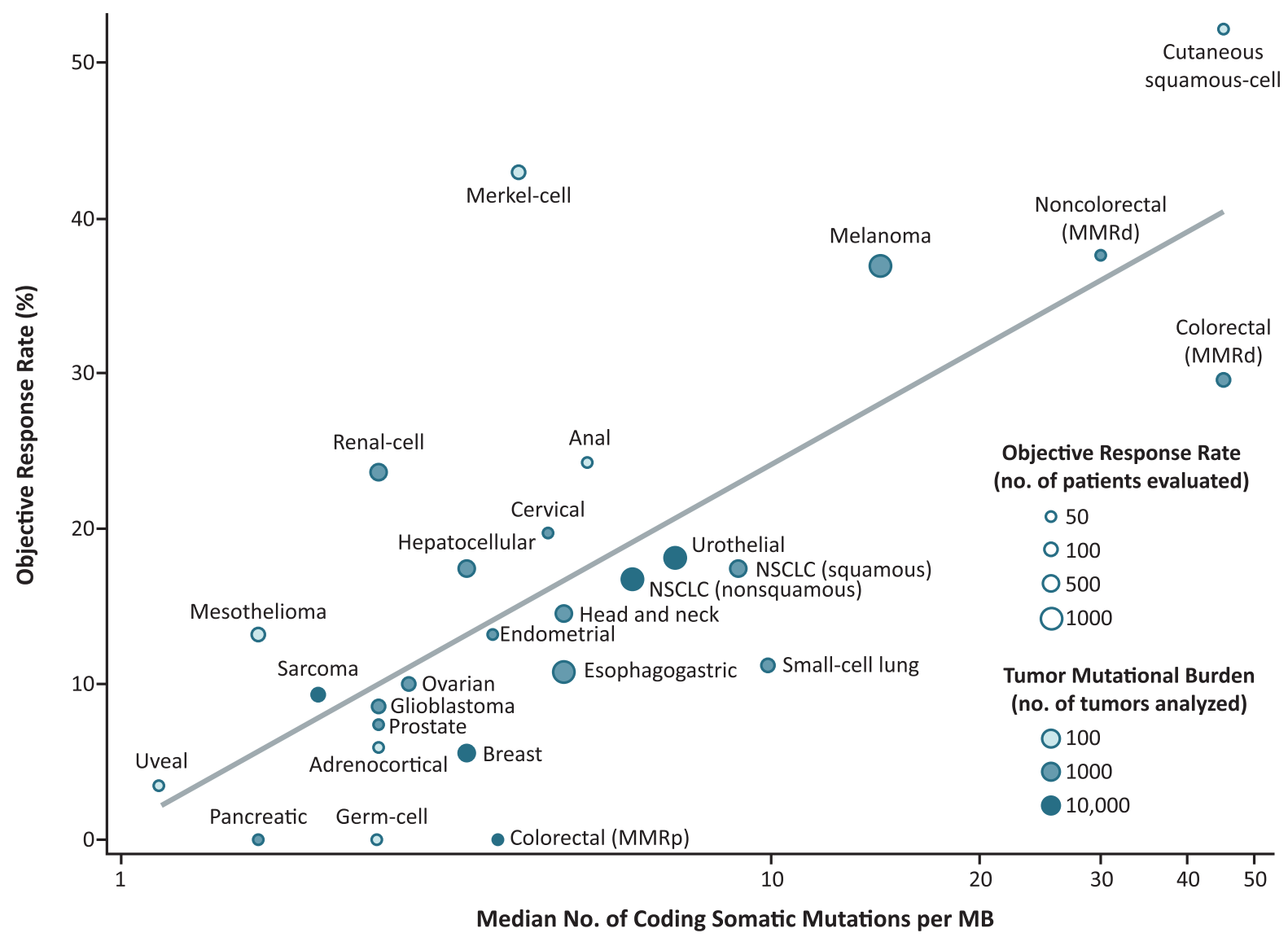

Figure 3. Correlation between coding somatic mutation frequency and objective response rates in diverse cancers [6]

\section{Clinical trials}

We can envision any potential immune therapy of blood cancer using along two strategies: antibody therapies and cell therapies. Antibody therapies can be further divided by technology such as unmodified antibodies, antibody-drug conjugates, antibody-radionuclide conjugates (radio-immunotherapy), bi-specific antibodies, and other more advanced techniques [7]. These data are summarized in the Table 1.

An example is gemtuzumab ozogamycin [8]. Clinical trials data are shown in Figure 4.

\section{PD-1 and CTLA-4 inhibitors}

Clinical studies of immune checkpoint inhibitors like antiPD-1 antibodies report little or no benefit. Current studies combine anti-PD-1 antibodies with anti-leukemic drugs [10].
A study in 22 subjects reported complete responses in 4 subjects with extra-medullary relapse of AML but not in subjects with bone marrow relapse [11].

\section{Cell-based immune therapy}

Cellular immune therapies use NK-cells and CAR-T- and CAR-NK cells and cytokine-induced NK-cells (CIK). My colleagues and I recently reviewed the current state of cell therapy of AML [12]. We discussed several approaches and concluded that although there are interesting preliminary data, there are no convincing data these approaches are a safe and effective treatment of AML. Perhaps the strongest current data are for NK-cells [13].

Synthetic biology techniques may allow use of anti-CD33 antibodies in AML by using CRISP/Cas9 to edit out CD33 from normal myeloid cells [14]. 
Table 1. Antibody-based therapies of acute myeloid leukemia (adapted from [7])

\begin{tabular}{|c|c|c|}
\hline Antibodies & CD33 & Lintuzumab \\
\hline & CD38 & Daratumumab \\
\hline ADC & CD33 & Gemtuzumab, SGN33A, IMGN779 \\
\hline & CD123 & SL-401, SGN-CD123A \\
\hline RIT & CD33 & 225AC-Lintuzumab \\
\hline & CD45 & 1311-BC8 \\
\hline Bi-specific & CD33 & AMG 330 \\
\hline & CD123 & $\begin{array}{c}\text { Nivolumab, Pembrolizumab, } \\
\text { Avelumab }\end{array}$ \\
\hline Checkpoint & PD-1/-1L & Ipilimumab \\
\hline & CTLA-4 & Assi Cur 0pin Hemato 2018 \\
\hline
\end{tabular}

\section{Conclusions}

In summary, immune therapy of AML poses challenges different from immune therapy of lymphoid-lineage cancers. There is progress, for example with gemtuzumab ozogamicin, but major challenges remain. There are potential advantages to immune therapy of AML compared with other cancers such as accessibility of AML cells and susceptibility to killing. However, negative aspects of immune therapy are requirements for antigenicity, immunogenicity, a low mutation rate and unacceptable reduced collateral damage to normal myeloid cells. Whether these challenges can be overcome is unknown. Hopefully so.

\section{References}

1. Foon KA, Smalley RV, Riggs CW, Gale RP. The role of immunotherapy in acute myelogenous leukemia. Arch Intern Med 1983;143:1726-1731.

2. Gale RP, Opelz G. Commentary: does immune suppression increase risk of developing acute myeloid leukemia? Leukemia. 2012; 26(3):422-423.

3. Gale RP, Opelz G. Is there immune surveillance against chronic myeloid leukaemia? Possibly, but not much. Leuk Res. 2017;57:109-111.

4. Horowitz MM, Gale RP, Sondel PM, et al. Graft-versus-leukemia reactions after bone marrow transplantation. Blood 1990;75(3):555-562.

5. Gale RP, Fuchs EJ. Is there really a specific graft-versusleukaemia effect? Bone Marrow Transplant 2016;51(11): 1413-1415.

6. Yarchoan M, Hopkins A, Jaffee EM. Tumor Mutational Burden and Response Rate to PD-1 Inhibition. N Engl J Med. 2017; 377(25):2500-2501.

7. Assi R, Kantarjian H, Ravandi F, Daver N. Immune therapies in acute myeloid leukemia: a focus on monoclonal antibodies and immune checkpoint inhibitors. Curr Opin Hematol. 2018, 25 (2), 136-145.

\section{Newly-Diagnosed AML 50-70 years}

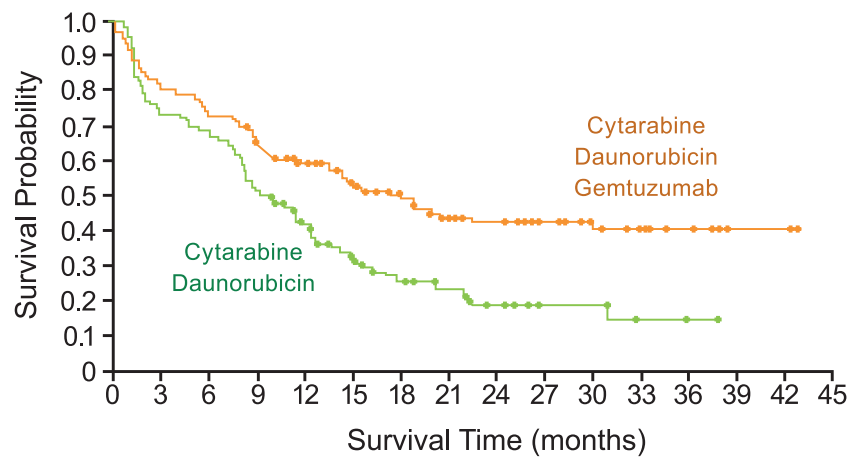

Figure 4. Improved long-term survival in persons with AML receiving or not receiving gemtuzumab ozogamycin [9]

8. Godwin CD, Gale RP, Walter RB. Gemtuzumab ozogamycin in acute myeloid leukemia. Leukemia, 2017; 31(9): $1855-1868$

9. Lambert J, Pautas C, Terré C, Raffoux E, Turlure P, Caillot D, Legrand O, Thomas X, Gardin C, Gogat-Marchant K, Rubin SD, Benner RJ, Bousset P, Preudhomme C, Chevret S, Dombret H, Castaigne S. Gemtuzumab Ozogamicin for de novo acute myeloid leukemia: final efficacy and safety updates from the open-label, Phase III ALFA-0701. Trial. 2019;104(1):113-119. doi: 10.3324/haematol.2018.188888.

10. Boddu P, Kantarjian H, Garcia-Manero G, Allison J, Sharma P, Daver N. The emerging role of immune checkpoint based approaches in AML and MDS. Leuk Lymphoma. 2018; 59 (4): 790-802.

11. Davids MS, Kim HT, Bachireddy P, Costello C, Liguori R, Savell A, Lukez AP, Avigan D, Chen YB, McSweeney P, LeBoeuf NR, Rooney MS, Bowden M, Zhou CW, Granter SR, Hornick JL, et al. Ipilimumab for patients with relapse after allogeneic transplantation. N Engl J Med. 2016; 375(2): 143-153.

12. Hansrivijit P, Gale RP, Barrett J, Ciurea SO. Cellular therapy for acute myeloid leukemia - current status and future prospects. Blood Rev 2019;doi.org/10.1016j. blre.2019.05.002.

13. Miller JS, Soignier Y, Panoskaltsis-Mortari A, et al. Successful adoptive transfer and in vivo expansion of human haploidentical NK cells in patients with cancer. Blood 2005;105(8):3051-3057.

14. Kim MY, Yu KR, Kenderian SS, Tsai SO, Dunbar CE, Saar Gill. Genetic inactivation of CD33 in hematopoietic stem cells to enable CAR T Cell immunotherapy for acute myeloid leukemia. Cell 2018;173:1439-1453. 


\section{Может ли иммунотерапия излечивать острый миелобластный лейкоз?}

\section{Роберт П. Гэйл}

Центр гематологических исследований, отдел иммунологии и воспаления, Имперский колледж Лондона, Великобритания

\section{Резюме}

Достигнут значительный прогресс в иммунотерапии различных злокачественных заболеваний. В области гематологии эти успехи ограничены в основном лимфоидными неоплазиями. Эффективные методы терапии включают моноклональные антитела и Т-клетки с химерным антигенным рецептором (CAR-T-клетки) к антигенам клеток лимфоидного ряда, таким, как CD19, CD20 и антигенам созревания В-клеток (BCMA). Гемтузумаб озогамицин $\left(\right.$ Миелотарг ${ }^{\circledR}$ ) является единственным препаратом, одобренным FDA для иммунотерапии острого миелобластного лейкоза (ОМЛ). Сообщают о нескольких клинических исследованиях антител к CD38 и $\mathrm{CD} 123$ с невысокой эффективностью и проблемами безопасности применения. Причинами являются: высокий уровень продукции миелоидных клеток и существенные повреждения нормальных кроветворных клеток в связи с недостаточной специфичностью в отношении клеток ОМЛ. Потенциальными мишенями для анти-ОМЛ терапии являются: (1) антигены системы HLA; (2) минорные антигены гистосовместимости; (3) лейкоз-ассоциированные антигены и (4) лейкоз-специфические антигены.
Данные в пользу эффективного аллогенного антиОМЛ эффекта основаны на исследованиях реципиентов гемопоэтических клеток с реакцией «трансплантат против хозяина» и реципиентов инфузий донорских лимфоцитов. Особой проблемой является относительный дефицит неоантигенов ОМЛ, по сравнению с солидными новообразованиями, что связано с низкой частотой накопленных мутаций. Исследования по клеточной иммунной терапии продолжаются, включая CAR-T-клетки, CAR-NK-клетки и аллогенные NK-клетки. Развиваются подходы с применением синтетической биологии. В настоящее время, кроме гемтузумаба озогамицина, отсутствуют убедительные данные об эффективности иммунной терапии при ОМЛ.

\section{Ключевые слова}

Острый миелобластный лейкоз, мутации, неоантигены, иммунотерапия. 